\title{
RATE REGULATION OF NATURAL GAS COMPANIES BY THE FEDERAL POWER COMMISSION
}

\author{
Charles I. Francis*
}

The scope suggested by the foregoing title is so broad as to require an introductory comment on what is to follow. Of necessity this article will attempt only to describe the current practice and policy of the Federal Power Commission (hereinafter referred to as the Commission), and comments or criticism with respect to those policies will be limited to but a few of the many problems encountered; also of necessity it presupposes at least some familiarity with rate and regulatory terminology and the general principles of rate making.

\section{Procedure}

The Natural Gas Act ${ }^{1}$ itself prescribes no set procedure with respect to rate hearings or rate action by the Commission. Briefly stated, the Act requires every natural gas company to file a statement of its rates, charges, etc., with the Commission and to file with the Commission any proposed change in a previously posted rate at least thirty days prior to the proposed effective date of such change, and authorizes the Commission to investigate effective rates either upon its own motion or upon complaint by an interested party. The exact procedures for this are specified in detail by the Commission's Rules.

Where initial rate filings of a new rate for a new service are involved, the Rules prescribe only the form and general content, ${ }^{2}$ since the Commission has agreed with the generally accepted opinion that an initial rate schedule cannot be suspended. ${ }^{3}$ Unfortunately, this rule and this lack of power have been substantially circumvented by the Commission's practice of attaching rate conditions to orders issuing certificates of public convenience and necessity. ${ }^{4}$ It has become common practice for the

* Member of the Texas bar; Vice President and General Counsel, Texas Eastern Transmission Corporation, Houston, Texas. Due acknowledgment is made by the author to R. Clyde Hargrove, Shreveport, La., Assistant General Counsel of Texas Eastern Transmission Corporation, for his assistance in the preparation of this article.

${ }^{2} 52$ STAT. 821 (1938), I5 U. S. C. \$\$7I7-7x7W (1946).

${ }^{3}$ Federal Power Commission, General Rules and Regulations, including Rules of Practice and Procedure, i 8 CODE Fed. REgs. §154.r (I949).

${ }^{3} I d$. $\$ 2.4(\mathrm{~d})$.

"No new sale or transportation of natural gas in interstate commerce may be commenced, nor may facilities be constructed therefor, unless the Company has first obtained from the Commission a Certificate of Public Convenience and Necessity authorizing such sale, service or construction. See 7 (c) of the Act, 52 STAT. 824 (1938), as amended, 56 STAT. 83 (r942), I5 U. S. C. \$7x7f(c) (Supp. I952). The Commission is empowered "to attach to the issuance of the certificate and to the exercise of the rights granted thereunder such reasonable terms and conditions as the public convenience and necessity may require." Sec. 7 (e) of the Act, 52 Stat. 824 (1938), as amended, 56 STAT. 83 (1942), I5 U. S. C. $\$ 717 f(e)$ (Supp. I952). 
Commission to require any natural gas company seeking authority to render a new service to justify in the certificate proceeding the rate which it proposes to charge for that service. Such certificate conditions sometimes require natural gas companies to change the rate level, and frequently the form, of such proposed initial rates by simply disapproving the proposed rate and requiring the filing of a rate schedule satisfactory to the Commission prior to the commencement of service. By this means the Commission, although it may not suspend an initial rate filing, may reject an initial rate submitted for filing on the ground that it fails to comply with a positive requirement of a condition attached to a certificate order. There is considerable doubt as to legality of this device, since it unquestionably grants to the Commission a power not otherwise conferred on it by the Act. The legality of the device has never been tested, and quite likely never will be, for the simple reason that natural gas companies seeking authority to commence new services or to construct new facilities are usually contractually obligated to operate on time schedules which do not permit them to raise the question. ${ }^{5}$

Investigation of natural gas companies' rates usually is commenced by an informal investigation by a limited field staff. If this informal check indicates that rates may be unreasonably high, discriminatory or otherwise improper, the Commission customarily orders a formal rate investigation. At this juncture, a fullfledged field staff usually moves in for an examination of the company's books and records. These investigations may consume comparatively little time or may extend over a period of years, and are not to be confused with the more or less routine audits of the plant accounts of natural gas companies conducted regularly by the Commission's accounting staff in order to determine the accuracy of a company's plant entries on an original cost basis. If the field staff's findings lead it to believe that the company's rates may be too high, discriminatory or otherwise improper, the Commission will then order a formal hearing, and it is on this record, not the field investigation, that the Commission must make its findings ${ }^{6}$ as to the reasonableness of the existing rates and fix the rate level, terms, and conditions and other elements of the company's tariff' for the future.

The procedure for filing for a change in an effective tariff was amended as of July I, I953, by the Commission's Order in its Docket No. R-I24. Briefly, it may be said that the changes of form, or of terms and conditions which are not considered to be an increase in the rate level, or of minor adjustments in rate level re-

\footnotetext{
${ }^{\circ}$ Many gas purchase contracts providing the gas necessary to support new sales contain a clause permitting the producer to cancel the contract unless the natural gas company secures a certificate by a specified date; frequently financial commitments and sales and other contracts also contain such "deadline dates." The conditioned certificate order could be appealed, but it is not unlikely that even if the court agreed with the company that the condition was illegal, it would also find that it had no power to issue a certificate, and would remand the case to the Commission to allow the Commission to determine whether a certificate should be issued at all if it had to be issued without a rate condition.

${ }^{6}$ Sec. 5 (a) of the Act, 52 STAT. 823 (1938), 15 U. S. C. \$717d(a) (Supp. 1952).

" 8 CoDE FED. REGs. \$I54.14 (1949) (Tariff or FPC gas tariff). The term "tariff" or "FPC gas tariff" means a compilation, in book form, of all of the effective rate schedules of a particular natural gas company, and a copy of each form of service agreement.
} 
quire only a relatively brief and simple statement in support of the changes. However, if the proposed changes will result in a major increase in rates, a voluminous amount of supporting data must be furnished concurrently with the filing of the new rates. The description of the data required to be filed fills nineteen typewritten pages, some single and some double spaced, and no attempt will be made to describe it in detail. ${ }^{8}$ Upon receipt of the filing, the Commission may suspend the increased rates, and order a hearing to determine the reasonableness thereof; as a matter of practice the Commission always follows this course when a major rate increase is filed. During such suspension period, the old rates continue in effect. After suspension and prior to hearing, much the same procedure is followed as was described above in cases where the Commission investigates effective rates. The Commission's suspension order may be effective for five months only, at the end of which time the natural gas company may place the increased rates in effect under bond. ${ }^{9}$ Since it is seldom possible to conduct a staff investigation of the increase, hold a hearing, file briefs, render an Examiner's decision, file exceptions, and make a final decision within the five month suspension period, the increased rates usually do go into effect under bond.

This exceedingly brief outline of the procedural aspects of the Commission's rate regulation leaves untouched many problems presented by the Rules, particularly with respect to the data which must be furnished in connection with the filing of an increased rate, ${ }^{10}$ but should be sufficient to indicate that the major and critical problem encountered is one of time. The Commission must have time to allow its staff to analyze the data filed by a company in connection with an increased rate filing or to analyze the books and records of the company in an investigation. The hearings themselves are extremely broad in scope, usually involve highly complex problems, and require a great deal of time for preparation as well as for actual hearing. At the same time a natural gas company cannot afford undue delay if a rate increase is urgently needed, ${ }^{11}$ nor should the public be subjected to undue

\footnotetext{
${ }^{8}$ I 8 CODE FED. REGS. $\$ 154.63$ (b)(3)(i) (1949).

${ }^{\circ}$ Sec. 4 (e) of the Act, 52 Stat. 822 (1938), 15 U. S. C. $\$ 7$ I7c(e) (Supp. I952). A bill has been introduced in the Senate (S. 2971, 83 d Cong., 2d Sess. (r954)) modifying this provision.

${ }^{10}$ The basic problem is whether the Commission is empowered to reject the increased rate itself where the Commission considers that the data required to be filed with such increased rate do not comply with the requirements of the Rules. The Rules themselves assert such a power.

${ }^{11}$ This is not an uncommon situation. A large percentage of the gas purchase contracts of many natural gas companies contain so-called "favored-nations clauses," which require the company to redetermine the price paid under those contracts at stated intervals, and to raise such price to the level of the highest price (within that producer's geographical area) then being paid by the company to other producers, or in some instances to the level of the highest price or the average of the three highest prices then being paid by any company to any producers. The activation of these clauses has resulted in the past and will result in the future in cost increases of millions of dollars per year. In such instances, it is absolutely essential that the company be able to place increased rates in effect, even if under bond, concurrently with the effective date of the increased cost of gas. The Commission's present Rule $154.63(b)(3)(i)$ is restrictive to the point of being dangerous in this regard. It requires that fnancial data submitted in connection with an increased rate filing "shall be based upon a test period consisting of 12 consecutive months of most recently available actual experience, adjusted for changes in ... costs which are known ... and which will become effective within seven months of the last month of available actual experience. . . It is physically impossible to record the results
} 
delay if a rate decrease is in order. The bonding procedure in connection with a rate increase filing affords some relief, but is not a satisfactory solution either for the natural gas company or for its customers. The natural gas company is collecting money under bond which it may have to refund in part or entirely, several years after it has been collected, together with 6 per cent interest thereon. The customer does not know whether the rate it is paying is actually a true expense to it or not; it may receive a substantial refund long after the close of the then current accounting period, and may be subjected to substantial unreimbursed expense in passing the refund on to its own customers. This problem is also magnified and aggravated by the fact that most customers of natural gas companies are municipalities or distributing utilities who must in turn base their rates to the general public on the cost of gas to them. In many instances, a chain reaction has occurred where a single rate increase filing by a natural gas company has resulted in filings for rate increases by several companies in a vertical line descending from each of several direct customers of the natural gas company.

A great deal of study has been given to possible improvements in procedure, either by amendment of the Rules or otherwise, which might reduce the time required to make a final rate determination. ${ }^{12}$ The gist of all of these studies has been and will be that the only possible solution is the maximum amount of cooperation between the natural gas company, its customers, and the Commission. Recently the Commission has adopted an aggressive policy of attempting to settle rates through negotiation between these three interested parties, and has met with considerable success in this effort. This is a long step in the right direction and can be used to further advantage so long as, and to the extent that, the three groups involved (the company, its customers, and the Commission) freely exchange all relevant data, restrict their demands to genuine needs and not bargaining material, and honestly try to settle any differences of opinion on a compromise basis. Above all, it requires complete confidence on the part of each member of the group that the other members are acting in the same good faith that it is. The natural gas companies themselves could facilitate matters through the maintenance of closer liaison with their customer companies, by keeping them advised in advance of the

of actual operations on the company's books and prepare the voluminous filing contemplated by the Rules in sufficient time to make the seven month period above cited coincide with the end of the five month suspension period which must elapse before rates may be made effective under bond. In all cases, the seven month period will elapse from one to three months before the five month suspension period, and even so short an interval as that between the onset of costs and acquisition of increased revenues could occasion staggering losses to a natural gas company. The only solution available to the company is to file data in addition to that required by the Rules, reflecting the onset of such costs on the date on which the suspension period ends. This is not only unduly burdensome; if the Commission staff maintains its current position, it almost certainly will file a motion to dismiss the entire filing, and the company must accept the risk of successfully combating that motion. This Rule secms almost deliberately designed to punish a natural gas company, and should be amended. As an aside, it might be added that under the present Rule the recently introduced Humphrey Bill (S. 2971; H. R. 7624), extending the suspension period from five to fifteen months, if enacted into law will bankrupt the first natural gas company faced with a major increase in costs under the "favored-nations clauses."

${ }^{12}$ Committes of the Independent Natural Gas Association are now studying this problem. They are expected to submit a comprehensive report to the Commission in the near future. 
possible or probable necessity of increased rates together with the reasons therefor, and by furnishing them with adequate data in support thereof.

\section{Substantive Rate Maring by the Commission: The Cost of Service}

The consistent policy of the Commission has been and is to allow rates which will produce revenues equal to the total cost of service; the first element of any rate case consequently is determination of the company's total cost of service. This may be defined as the sum of the expenses (including depreciation and income taxes) incurred by the company during a given test period, plus a reasonable return to the company. Once the total cost of service has been determined, it is necessary to determine what share of that total should be borne by jurisdictional and nonjurisdictional business, ${ }^{13}$ and what share of the total attributable to jurisdictional business should be borne by the various rate zones and types and classifications of service offered by the company, if there are multiple zones and types and classifications of service. The problem of making these allocations on a proper basis is easily as complex and involved as making a proper determination of the total cost of service in the first instance. Not only do most natural gas companies disagree with the allocation methods employed by the Commission, but many of them also disagree with each other. No attempt will be made here either to analyze the Commission's allocation policies, or the views of any individual company or rate analyst, other than to point out that if the wide difference of opinion on the subject proves anything it must prove that allocations cannot be made by formula but must be made on the basis of the facts peculiar to the individual company and the individual rate or service involved.

Two comments must be made in connection with any discussion of the use of cost of service by the Commission as a basis for determining rates. The first is that the Commission should not necessarily fix an individual rate, where a multiplicity of zones or types of rates exist, on the basis of a mathematically allocated cost of that individual service. This is not to say the total revenues should not be measured by the total cost of service, but only that the revenues realized from an individual rate or rate zone should not be closely conformed to a complicated and highly controversial calculation of the cost of serving that rate or rate zone. Several elements may be entitled to consideration along with the mathematical figures.

Historical considerations are usually worthy of great weight, and indeed have frequently been given great weight in the past. This is not an argument in favor of allowing a rate which clearly has been too low in the past in relation to the total cost of service to remain too low; it is no more and no less than a statement that the impact of an abrupt adjustment to a proper proportionate level may need to be considered, particularly if the proportionate adjustment is coupled with a substantial increase in the over-all cost of service.

${ }^{13}$ Direct sales to industrial customers are not subject to rate regulation by the Commission. Sec. I(b) of the Act, 52 STAT. 822 (1938), 55 U. S. C. \$717(b) (Supp. I952). 
Another factor entitled to serious consideration is the value of the service to the customer. If a particular type of service is of exceptional value as compared to other types of service (an example might be a firm supply of winter or peak day gas with no corresponding obligation to buy in the summer or off peak period as contrasted with a routine day-to-day supply and obligation to buy), this factor should be carefully considered and weighed along with the mathematically allocated cost of that service.

Another factor which may be considered is the size of the customer. A distributing utility customer of a natural gas company serving a very small community may and probably does lack the same opportunities for development of a varied load as are available to a distributing utility customer serving a densely populated and highly industrialized area. This factor has been given consideration by many natural gas companies in the establishment of special rates applicable only to small customers, which special rates in most cases probably do not produce revenues equal to the mathematically allocated cost of service.

Situations may also arise in which it is impossible, or inadvisable in the public interest, to establish rates by use of the cost of service method. For example, if the Commission has rate jurisdiction over the independent natural gas producer, and actively assumes that jurisdiction, it is difficult to see how those rates (the field price of gas) can be regulated on a cost of service basis. The larger natural gas companies have a tremendous number of gas purchase contracts with different producers, some of whom produce gas from the same field or even the same producing horizon of a field. All of these have different capital costs and different operating expenses. The sheer physical task of attempting to regulate so many different operations on a cost of service basis must be impossible of accomplishment unless the staff of the Commission is multiplied many times, and probably impossible even then. Second, the use of a cost of service as applied to an independent producer would be, in the opinion of many competent students as well as this writer, inadvisable and contrary to the public interest. Since any argument on this point, either pro or con, would likely consume more space than is contemplated for this entire article, no discussion of this proposition will be attempted. ${ }^{14}$

\section{The Test Period and Determination of Expenses}

As previously stated, the cost of service is developed over a period of time considered proper for testing the reasonableness of the proposed or effective rates. Selection of a proper test period can be a matter of crucial importance; for example, the volume of sales, the level of unit costs, the size of the plant, all may vary considerably from year to year. In general, the Commission requires that the test period used be a past period where actual book figures and experience are available, but estimates for the future may be permissible or necessary in any given case. If, at the time the rates are to be determined, the company has recently undergone such

\footnotetext{
it See article by author, Federal Regulation of Interstate Shipment and Sale of Gas, Fourth ANwUAL Institute on OIL and Gas Law and Taxation ro3 (Southwestern Legal Foundation, 1953).
} 
a sizable expansion that its past operations are no indication of what its future operating results will be, then the reasonableness of the rates proposed for the future must be tested by what its operations will be and not by what they once were but never will be again.

However, certain problems commonly occur no matter which test period is used. The most common is the adjustment of past experience to reflect known changes in costs that have occurred or will occur prior to or at the time the new rates become effective. The company must sustain the burden of proof that such a cost adjustment is definite and certain and not merely speculative, and of properly applying that adjustment to its experience figures. A second common problem is the non-recurring income or expense item. The first phase of this problem consists of determining whether the item is in fact non-recurring. If it is, it then must be determined whether it should be disregarded in fixing rates for the future, or whether it is so sizable or so closely related to a capital item that equity requires that it be amortized over a given period of years.

The thorniest expense determination problem of all, and the one which unquestionably has received the most publicity, is the determination of the field price of gas to be included as an expense where the natural gas company itself, or an affiliated company, is the producer. To date, the Commission has found such cost to be a cost of service determined from actual operating expenses, and allowed a return on the original cost of the investment less accrued book depreciation. ${ }^{14^{2}}$ As might be expected, this has resulted in a tremendous disparity between expenses allowed a natural gas company for the use of its own gas and the expenses allowed where the gas was purchased from an independent producer. So much has been written and said on this subject that there is little that can now be added. ${ }^{15}$ One comment should be made, however. If the field price of gas produced by a natural gas company, or its affiliate, is to be determined on a cost of service employing an original cost rate base, then surely the rate of return, if it is to give any reasonable recognition of the risk element involved, should be far in excess of that applied to the natural gas transmission business.

\section{RETURN}

The return element of the cost of service is the product of the rate base of the natural gas company multiplied by a reasonable rate of return expressed as a percentage of that rate base. In as much as the determination of the net rate base

\footnotetext{
${ }^{14 a}$ Since this article was written, the Commission by a 4 to 1 decision in Opinion 269 , In the Matter of Panhandle Eastern Pipe Line Company, Docket No. G-11I6 et al, issued April 15, 1954, has reversed this position and allowed the natural gas company the "fair field price" for its own gas.

${ }^{15}$ For exhaustive discussions of different points of view on this subject, see the Smith-Wimberly Report and the Draper-Olds Report, both based upon the Commission's Natural Gas Investigation, Docket No. G-580 (1948). The author was counsel in these proceedings for a very large section of industry, including, among others, the American Petroleum Institute, and urged through witnesses, briefs, and arguments, the allowance to natural gas companies of the fair field price for their own gas, the nonregulation of arm's-length gas purchases, and the abandonment of the "vanishing rate base" theory.
} 
involves consideration of depreciation allowances and handling of the depreciation reserve, that subject must be considered concurrently with any discussion of return.

\section{RATE BAsE}

In so far as the Commission is concerned, the rate base of a natural gas company is the original cost of its plant which is used or useful in the natural gas business, less accrued book depreciation, plus working capital. From an administrative standpoint, the use of this standard for determining a rate base has been of great advantage to the Commission. As of today, the original cost of the plant of most natural gas companies has been determined, and the Commission has maintained a policy of periodic field audits of the books of natural gas companies in order to approve or disapprove accounting entries for capital items, whether the natural gas company was at that time involved in a rate proceeding or not. While it has been impossible for the Commission to keep exact pace chronologically in checking such plant accounting entries, it is believed that it has checked most larger companies through very recent dates.

The Commission has been aided considerably in keeping up-to-date checks on plant accounts, not only through the use of the original cost method, but because of the existence of its certificate powers.

Since the Commission must find that any proposed new facilities are required by the public convenience and necessity in order to issue a certificate therefor, ${ }^{10}$ it must pass in advance on the feasibility and need for any such plant additions. Although neither the Act nor the Rules specifically so state, it seems clear that once the Commission has found that such additions are required, they must be included in the rate base as used or useful in the natural gas operations of the company. Questions with respect to the includability of certificated property in the rate base should be raised only when such property has not actually been constructed and placed in operation at the time of the rate determination. In such instances, the property should nevertheless be included in the rate base if during the period selected as a test period such property would be necessary or useful in order for the company to fulfill its obligations and provide the services from which it had been assumed revenues would accrue.

Properties not certificated by the Commission but which may be considered in determination of the plant account are of two kinds: (I) Those for which no certificate is required, such as gathering lines; and (2) those for which a certificate is required but for which the certificate has not been issued or the properties constructed.

With respect to the first classification, the property is clearly includable in plant account if it is in fact used or useful in the company's natural gas business. The burden of proving this fact is upon the company. The second classification should be includable subject to the same test as that applied to property certificated but not

${ }^{16}$ Sec. 7 (e) of the Act, 52 STat. 824 (I938), as amended, 56 Stat. 83 (I942), 15 U. S. C. 57 I7f(c) (Supp. 1952). 
constructed; however, the Commission's present Rules reflect the current position of its staff that such uncertificated properties may not be included in the plant account. Rule $154.63(\mathrm{~b})(3)$ (i) provides in part: "Adjustments to experience ... may include the amounts for facilities for which a permanent or temporary certificate is outstanding, provided such facilities will be in service within the test period, but shall not include any amounts for facilities in respect to which a certificate of public convenience and necessity must be obtained, but which has not been issued at the date of filing. ..."

This provision of the Rules is not necessarily determinative of the question, for the Commission has recognized that a natural gas company may submit data other than that specified in the Rules if it has relied on such data in support of a rate increase. $^{17}$ Logically there seems to be no justification for differentiation in the treatment accorded to certificated and uncertificated properties when the properties have not been constructed, except in the standard of proof to be required of the natural gas company. Existence of the certificate order serves only to prove that the property when constructed will be used or useful in the business, and clearly this fact should be susceptible of proof in the absence of a certificate. Similarly, since the property is not actually constructed and in use it should not be includable in the plant account unless a test period has been selected ${ }^{18}$ which requires the assumption that the property has been constructed and is being used. The test should not be the existence or non-existence of a certificate, but the proper period to be selected for the determination of the company's rates, with a corollary assumption that all property required to render the services needed to produce the assumed revenues was in service during such period.

While this article will not attempt to discuss other methods of determining the plant account than original cost, it is apparent that the weaknesses inherent in any original cost determination are necessarily present in the Commission's use of that method. The most critical of these is the rigidity of an original cost determination during an inflationary or deflationary spiral in general price levels. It is an unquestionable fact that it would cost far more today to construct a plant capable of transporting any given quantity of natural gas than it originally cost to construct such a plant even a few years ago. It should be equally clear that basing a return on a plant whose original cost was, say, $5^{0}$ per cent of its present day value, severely penalizes the company's equity owners in both a practical and an economic sense. At the same time, the administrative efficiency of the original cost determination cannot be denied. This writer and others have suggested that the original cost of the plant might be adjusted by the use of a simple index weighting the cost per ton of steel and the cost of labor. This would impose no administrative difficulties and

${ }^{17}$ Sec. 154.63 (b) (3) (i) of the General Rules and Regulations: "If, in addition to the data specified in Statements $A$ to $N$, the natural gas company has relied on other data in support of its rate increase, such other data, appropriately identified and designated as such and separately stated, shall be submitted."

${ }^{18}$ The test period would not necessarily have to be a future test period; frequently adjustments must be made to past experience, to account for events which have not occurred but which definitely will occur in the future, which produce the same results as the use of a future test period. 
would result in a rate base far more nearly approximating the "fair" or "present value" of the company's plant than unadjusted original cost. It is subject to the criticism that, since both bond interest and preferred stock dividends are fixed by contract and remain constant and related to the original plant cost despite fluctuation in the general price level, adjustment of the entire rate base in the amount suggested would result either in an undue windfall to the common stockholders during an inflationary period, or an undue penalty to common stockholders, and possible impairment of the company's ability to meet preferred stock dividends and bond interest payments, during a deflationary period. As a result, some economists have suggested that such adjustments might better be reflected in the rate of return than in the rate base. ${ }^{19}$ The writer has no quarrel with this; it is immaterial either from a practical or a theoretical standpoint where the adjustment is made to reflect general price fluctuations so long as an adjustment is made, and so long as it is made consistently and not just during a deflationary period. Possibly the best approach to this problem is that which has been advocated by some economists and by at least one witness before the Commission in recent rate cases. ${ }^{20}$ This solution would adjust by the use of designated indices the determination of the cost of money as an element of the rate of return, by applying such indices to the equity portion only of the cost of money determination. It would seem that this solution both satisfies the requirements of administrative efficiency and answers the economic objections to adjusting the rate base by indices, while at the same time it recognizes and gives effect to the impact of changing general price levels.

While working capital is theoretically added to the net plant account in arriving at a total rate base, it is not a material item under present Commission practice; indeed, it frequently is not an item at all. After determining the total working capital allowance, the Commission then credits against that total the cash accrued in advance for income tax payments. This cash figure is fixed at 75 per cent of the current year's income tax accruals, which amount except under most unusual circumstances is substantially all of the working capital allowance and frequently exceeds it.

Admittedly there is some justification for this, at least in so far as cash working capital is concerned, for a company does accrue taxes, and collect cash on that accrual, well in advance of the date on which such taxes must be paid. There is, however, no justification for the determination of cash working capital requirements from a fixed formula. The Commission allows 45 days' operating expenses, exclusive of the cost of gas and certain other costs, as a cash working capital allow-

${ }^{10}$ Eli W. Clemens, Economics and Public Utillties 153 (1950); Irston R. Barnes, Tue Eco. nomics of Public Utility Regulation 415 (1942).

${ }^{20}$ See the testimony of Dr. J. Rhoades Foster in the following hearings before the Commission: In the Matter of Panhandle Eastern Pipe Line Company, Docket Nos. G-r1r6, G-1317; In the Matter of Texas Eastern Transmission Corporation, Docket No. G-1964; In the Matter of Transcontinental Gas Pipeline Company, Docket No. G-2075; In the Matters of Pacific Power and Light and Mountain States Power Company, Docket No. U-S-1723. Dr. Foster has advocated the same approach in testimony before the Maine, Massachusetts, Ohio, and Illinois Commissions. Also, see the excellent article by Walter A. Morton, Rate of Return and the Value of Money in Public Utilities, 28 LAND Economics 91 (1952). 
ance; in many instances this simply does not approach the amount of cash which a company must keep on hand. The larger natural gas companies have enormous cash requirements, it being estimated that minimum bank balances of five million dollars should be available at all times for efficient operation. In any event, the amount of cash working capital (or minimum bank balances) required can be determined in the case of any given company, and should be proved as a fact rather than determined by formula.

\section{DEPRECIATION}

Since the rate base is customarily plant original cost less book depreciation accrued on a straight line basis, consideration of the depreciation practices of natural gas companies is essential to any discussion of the propriety of this method of determining rate base. No attempt will be made to enter into an economic analysis of what depreciation is or how it should be determined; this article is concerned with the practical effect of current Commission policies on natural gas companies.

A depreciation allowance for a natural gas company must take into consideration not only all those factors customarily considered by utilities in general, but also certain features peculiar to natural gas companies. The first and most important of these is a depletion element which must be recognized in the depreciation allowance since there is no other appropriate place for it. A natural gas company is worthless unless it has gas to transport and sell; as the gas reserves owned by or committed to it are depleted, there is an attendant loss of value or future earning capacity unless those reserves are currently replaced. As of a given date, however, the company can only foresee an assured gas supply for a relatively limited period. This is not a matter of undue concern to the management of natural gas companies, since they are unanimously confident that so long as the rate of discovery continues as it has in the past, there is no serious probability that they will be unable to replace reserves currently being consumed; however, prudent management must give recognition to the fact that they can take into account only known reserves. Even if they were not inclined to do so, they have been left no choice in the matter, since this factor has caused the bondholders of virtually all natural gas companies to insist upon very high sinking fund requirements. These frequently are fixed at a rate adequate to retire the bond issue within 20 years; furthermore, within the past few years sinking fund requirements have been tied to available gas reserves through a requirement that periodic certificates of gas availability, prepared by independent engineers, be furnished to the trustee under the bond indenture. If this certificate of gas availability reflects a reduction in gas reserves available to the company over the life of the bonds at a rate greater than that anticipated at the time the bonds were issued, the sinking fund requirements are increased accordingly. This provision is common to most natural gas bond issues today, and is by contrast to the sinking fund requirements of electric utility bonds, where the retirement often is spread over a period of 50 years or more. These high sinking funds impose heavy cash requirements on natural gas companies, and this cash is available only from the de- 
preciation and the return allowances. Since common and preferred stock dividends and bond interest must be paid from the return allowance if the company's credit is to be maintained and it is to continue to be able to attract capital on a favorable basis, it is apparent that the cash for the sinking fund requirements must come from the depreciation allowance. Consequently, the depreciation allowance must be sufficient to take into account not only management's appraisal of the depletion factor, but also the bondholders' appraisal of the depletion factor. As a result, depreciation allowances usually range upwards of 3 per cent, with 3.5 per cent not uncommon, and 4 per cent not unreasonable in many instances.

A second factor more pronounced in the natural gas industry than in the case of the electric utility is the possibility of industry obsolescence. While there has been increasing use of natural gas as a raw material in the manufacture of chemicals, for all practical purposes a natural gas company sells or transports heat, and nothing but heat. Any technological development which may provide a better or cheaper source of heat could render the natural gas industry obsolete, at least in its present proportions. This is not true of the electric industry, which itself converts heat or water power into electric energy. For example, widespread use of atomic energy on an industrial or even residential basis might well eliminate the natural gas industry, while merely providing the electric industry with another source of power. Although this factor obviously is not susceptible of measurement, it must nonetheless be considered in management's determination of a prudent depreciation allow. ance.

A third element which must be considered is economic depreciation during an inflationary spiral, ${ }^{21}$ when the cost of replacement of a given capital item substantially exceeds the original cost of that item. This need not necessarily be considered in the determination of the depreciation allowance, if the impact of general price fluctuations is given consideration in the rate of return allowance or by adjustment of the rate base. Since the Commission has not yet given any consideration whatsoever to the impact of general price fluctuations in determining either the rate of return or the rate base, it may well become prudent for management to give serious consideration to the reflection of this factor in the depreciation allowance; it should be said, however, that in so far as the Commission records reflect, no specific recognition has been given to economic depreciation to date either by management or by the Commission in the fixing of depreciation allowances.

The result of consideration of all these factors is a larger depreciation allowance on a straight line basis than is necessary to maintain the physical integrity of the plant; or, to put it differently, it is a larger allowance than would be determined by consideration of the service life of the physical facilities alone. The predictable result of this, assuming that industry obsolescence does not occur and that the current rate of discovery of gas reserves continues for even a relatively short period of time, is that natural gas companies will be operating plants at full efficiency long after

\footnotetext{
${ }^{2 x}$ This element, of course, is common to all utilities.
} 
those plants are fully or substantially depreciated on the books. This is the most critical problem facing the gas industry today.

\section{The Vanishing Rate Base}

Although the Commission's practice of determining rates by the use of a rate base consisting of unadjusted original cost of plant less accrued book depreciation is of long standing today, insufficient consideration has been given to the impact of this policy on the natural gas industry. Writers and economists not directly associated with the industry have hardly touched upon it; commissions, with a few notable exceptions, have ignored it; even the industry itself has made no vigorous attack on the policy. ${ }^{22}$ In so far as the natural gas industry is concerned, the reason for this laxity can be understood: almost from the day the Natural Gas Act was passed, the industry has undergone an unparalleled expansion with new companies being created and both old and new companies not only increasing but actually multiplying both the physical capacity of their systems and the size of their gross plant accounts. As a result, plant accounts have increased consistently and spectacularly, and the impact of deduction of accrued book depreciation has not been felt severely. But while the laxity of the Commission in adopting this policy and of the industry in accepting it may be understandable, it is by no means excusable. One industry spokesman has put the problem succinctly as follows: "To prove my point I submit that in a static property whose plant account is unchanged the ultimate result will be to extinguish the rate base (except for working capital and other minor items), thereby completing the transfer of the property from the company to the consumers. Legal title would, of course, remain in the company but a sort of trusteeship would prevail ... It is no answer to say that few properties are static and that it would take many years to achieve the ultimate. This only argues that the impact is mitigated, but the illustration of what is taking place is still valid." ${ }^{, 23}$

The justification for the deduction of accrued book depreciation from the original cost of the gross plant lies in the argument that the depreciation allowance is included as an expense in determining a natural gas company's current rates, and that its customers in paying those rates have returned that amount of capital to the company. Consequently, so the argument goes, the customer should not be required to continue to pay a return on capital already returned to and held by the company; this would occur if an undepreciated plant account were used as a rate base. This is perfectly true as far as it goes, but it fails to take into account many factors which should be considered in all equity.

In the first place, it overlooks or disregards the broad objective of rate regulation. "In a broad sense, the objective of public utility rate regulation is to achieve

22 An exception to this is the outstanding article by Ralph M. Besse, Should Depreciation Be Deducted?, 45 Public Utilities Fortwigrrix 822 (1950). Others have recognized the existence of the problem but apparently have not considered it a matter of great concern.

${ }^{23}$ Testimony of R. H. Hargrove, Federal Power Commission Docket No. G-580. 
through regulation the same result that would be achieved by competition."24 To translate this into practical terms, deduction of accrued depreciation reduces the rate base to or approaching the vanishing point, thereby eliminating any substantial allowance for return to a natural gas company (and also eliminating the income taxes associated with such return). Assuming that other costs remain relatively fixed during this process, rates to the ultimate consumer would be reduced substantially and tend to remain at a permanently low level; this would not be true of a competitive enterprise, where prices are not primarily determined by the amount of capital employed. In such instances, the price is fixed by competitive forces, and capital structure enters the field only when a competitor can no longer meet competition because its capital structure will not permit it to survive on a lower return. To the extent that reduction or elimination of the rate base reduces prices below what they would have been in the presence of a competitive market, the industry is being overregulated. This statement is so susceptible of being misinterpreted as a plea to allow natural gas companies to charge prices based on competitive levels that it requires clarification, for the fact is that natural gas does sell in a competitive market.

No natural gas company is a monopoly, or approximates being a monopoly, even within a given service area. Competition is continuous and severe with alternate fuels, principally coal and oil, and is present to some extent with electric power. The industry is not being overregulated if its prices are fixed at a level below that of its competitors, so long as that low price is determined after allowance of a reasonable return. It then is in the enviable position of being able to force its competitors down in price, or of being afforded a continuous and ever increasing demand for its product-a demand which it will be happy to supply by continued expansion, if it is receiving a reasonable return on that expansion. On the other hand, the natural gas industry is being overregulated if its prices are maintained below competitive levels because it is not being allowed a reasonable return; in such a case it again will either force its competitors down in price, or be afforded a continuous and ever increasing demand for its product. In this instance, however, the result is contrary to the public interest: if competitors, due to the presence of an artificially or uneconomically low price, are forced in turn to sell at an uneconomically low price, they in turn will lose earning power and ability to attract capital, and, sooner or later, will be driven from the market; if, as is more likely, they continue to charge noncompetitive prices and still retain enough market to survive, due to the inability of natural gas to supply the total demand, natural gas is faced with an artificially induced demand which it will become unwilling to supply due to its inability to continue to obtain a return it considers adequate-investors will take their funds elsewhere.

As of today, the above analysis is purely theoretical, for reduction or elimination of any return to a natural gas company will not result in permanent reduction in the

${ }^{24}$ Clemens, op. cit. supra note 19 , at 153. 
rate charged consumers unless the company's other costs become fixed, or relatively fixed. As of this moment, those other costs are not fixed. By far the most important element of the cost of service of any natural gas company is the cost of gas, and the field price of gas produced by producers not affiliated with natural gas companies is not regulated by the Commission. This price has risen spectacularly in the past few years, and in the absence of regulation will continue to rise until it reaches a competitive level in the market area with alternate fuels. In short, it may safely be assumed that the field price of gas and other costs will rise to fill the gap between the regulated price and the competitive price at the natural gas company's point of delivery. It follows that if the industry's return is eliminated or unduly reduced through the elimination or reduction of its rate base, the industry is operated and regulated for the benefit of either the nonaffiliated producer or the consumer, depending on whether or not the field price of gas is regulated. In either case, the result to the natural gas company is disaster, for ultimately it must lose first its incentive or willingness to continue to meet demands, and then its ability to do so. In either case, the Commission will have failed to achieve the broad objective of rate regulation by failing to produce results approximating competitive action, for even if competitive market prices are maintained by increased field prices of gas, the producer will be receiving a non-competitively high price for his share of the competitive market area price. At the same time, the public interest is dealt a severe blow, for the failure of private industry, already subject to regulation, to continue to supply the demand for its product ultimately compels public ownership-and this is particularly true where the demand is artificially stimulated by an uneconomically low price in a competitive market. ${ }^{25}$

In a more immediate and readily ascertainable sense, the argument justifying the deduction fails to consider that, while cash may be returned to the company as capital through the allowance of depreciation as an expense in the fixing of rates, the depreciation reserve cannot be paid out in the form of either preferred or common stock dividends; these must come from earnings. In other words, while the company as an entity may have received a return of capital, it has not been returned to the investors who supplied it in the first place. This reserve must be held as a trust fund to insure the physical integrity of the plant and its continued performance in the public service. The owners of the company find themselves with frozen capital on which they are allowed no return. The obvious answer to this is that the depreciation reserve may be invested by the company and earn a return, and in fact is being invested by all natural gas companies either by its use to meet sinking fund payments and retire indebtedness, or to finance expansions; in either case it has in effect been invested in the company itself.

There are at least two sound rebuttals to this answer. The first is that to the extent that cash from depreciation allowances is used to retire indebtedness, the

\footnotetext{
${ }^{35}$ Advocates of public ownership might consider this to be very much in the public interest. We do not propose to argue this, but whatever the merits, if any, of public ownership of some industries may be, it would be a difficult operation indeed in the natural gas industry.
} 
company earns a return equivalent only to the interest rate on that indebtedness, but is charged with the full rate of return allowed by the Commission when the depreciation accruals are deducted. This is a severe loss in earning capacity. Even if the depreciation accruals are used to finance expansions, the company does no more than break even; it is charged with the full return on the deduction and credited with the full return on the expansion. This process overlooks the risk element inherent in any expansion, for the company is thereby forced to expand not in order to improve its earnings, but to maintain them. If the expansion proves unprofitable the equity owner, not the rate payer, sustains the loss, and the risk of this result has been assumed without any compensation whatsoever.

The second rebuttal to be made to the answer that the depreciation reserve may be invested is that it necessarily assumes that opportunities for investment exist. Once the company's indebtedness has been retired, and that enforced investment dissipated, it is entirely possible that no advantageous investment may be made in the company itself other than such investment as may be necessary in order to maintain the physical integrity of the plant, which is usually less than the total depreciation allowance for natural gas companies. ${ }^{26}$ This does not mean that other advantageous investments would not be available, and undoubtedly these would be utilized by the company, but as the depreciation accruals continued to mount and the rate base to decline, the interest and attention of the management and owners of the company would become focused on its investment business, not on its natural gas transmission business. Not only theoretically but as a concrete possibility, a natural gas company could arrive at the stage where it became primarily a large investment trust which only incidentally operated a gas transmission system. It is axiomatic that lack of interest in its utility business on the part of a public utility or in its natural gas business on the part of a natural gas company is contrary to the public interest. ${ }^{27}$

Criticisms of the policy of deducting accrued book depreciation from an original cost rate base are not new. ${ }^{28}$ The problem arises in finding the means whereby

${ }^{20}$ This may not be true for utilities generally. BarNes, op. cit. supra note 19, at 265, states: "Unless a company continues to expand, the time comes when annual retirements are approximately equal to the annual charges for depreciation, and the reserve will thereafter tend to be stabilized. The reserve for a mature property approximates 50 per cent of the value of its depreciable property." It is hardly possible that the average natural gas company would stabilize at a figure as high as Barnes' 50 per cent; in any event, the thought that the rate base may only be cut in half instead of eliminated entircly is hardly a comforting one.

25 BARNes, op. cit. supra note I9, at 278: "As a matter of public policy, the utility should probably be under a heavy burden of proof to justify entry into businesses other than its principal public service. ..."

${ }^{28}$ Besse, supra note 22; Clemens, a leading exponent of the use of original cost less accrued deprcciation, states at page 214: "This writer does not regard all questions as closed. In some quarters, a ceiling on depreciation reserves has been recommended. It is perfectly possible that reserves might reach a level of 50 per cent or more of property values. It is doubtful whether reserves of say 30 per cent should be built up. Certainly it does not seem necessary or wise to go to extreme lengths to build reserves up to some high and theoretical age-life level. The ratepayers shouldn't be burdened with the expense, nor does it seem necessary to punish the utility stockholders in service of a theoretical accounting fetish. This is not to argue for retirement accounting. The argument is mercly against huge reserves. 
the consumer may be given credit for the capital he has returned in the form of the depreciation allowance, while at the same time avoiding elimination or serious impairment of the natural gas company's earning power. An equitable solution could be based on a method employed by the Missouri Commission. ${ }^{29}$ That method uses an undepreciated rate base, but credits the total cost of service with an amount equal to 3 per cent on the accrued book depreciation. This gives the consumer credit for the capital he has furnished, but does not charge the company with excessive earnings from the investment of that capital. The use of a figure of but 3 per cent as assumed earnings from investment of the depreciation reserves is subject to criticism for being too low in many instances; it is submitted that an undepreciated rate base should be used, and that the cost of service should be credited with an amount determined by an analysis of the use to which the depreciation reserve has been put. $^{30}$ For example, to the extent that the depreciation reserve has been used for sinking fund purposes, the cost of service could be credited with the interest or dividends on the securities retired. ${ }^{31}$ To the extent that it has been invested in property replacements which maintained the physical integrity of the original plant, the cost of service should be credited with the full rate of return allowed the natural gas company. To the extent that it has been invested in plant expansion, the cost of service might be credited with an amount in excess of the cost of senior capital but less than the full rate of return in order to allow some credit to the natural gas company and its equity owners for the risk entailed. To the extent that it has been invested in enterprises not associated with the company's natural gas business, the cost of service might be credited with the return actually received from such other business; this would be a strong deterrent to the entry into non-utility fields, since no net profit could accrue to the company therefrom, and it probably would simply invest its excess cash in government bonds. To the extent that it has been invested in enterprises other than the company's jurisdictional natural gas business, but closely associated with that business (such as production subsidiaries and exploration companies, oil and gas research enterprises, transportation subsidiaries for the transmission of oil, gas or their products, company-owned insurance companies or investment funds with participation limited to company employees, and so forth), a more liberal treatment might be afforded than charging the cost of service with the entire return received from such investments. In such instances, the cost of

"Both straight-line and sinking-fund accounting imply that the accumulated reserve can be used in the business. This is not always true. The utility may already have adequate working capital. If business is declining, it might be impossible to reinvest the funds represented by the reserve in earning property. The situation is made worse if the entire amount is deducted in determining the rate base or if the utility is charged interest on the reserve." CLEMENs, op. cit. supra note ig.

${ }^{\text {20 }}$ Case No. 10723, Order dated Dec. 28, I945.

${ }^{30}$ While such an analysis would not be simple, it could be made. The Commission already determines interest during construction by tracing the source of capital invested during the construction period, and varying the amount of interest allowed to reflect the proportionate use of bond proceeds, preferred stock proceeds, and common stock proceeds.

${ }^{31}$ Many natural gas company preferred stock issues also are subject to sinking fund requirements. 
service might be charged with the return which such associated enterprises paid on their own senior securities.

A second solution simply would be to stop accruing depreciation at some point. This point might arbitrarily be fixed at a percentage of the gross plant, or at an amount equal to the equity investment, thereby allowing accruals to continue until senior securities had been retired. Until that point was reached, the customary depreciation allowance would be included as an expense item, and accrued depreciation deducted from gross plant. Thereafter, depreciation expenses could be limited to those actually incurred in replacements necessary to maintain the physical integrity of the property, and accruals would cease unless and until an expansion was effected or it became apparent that the arbitrarily fixed reserve was inadequate. ${ }^{32}$ This solution is inequitable since the reserve accumulated would earn only the senior security return whereas the company would be charged with the full rate of return by means of the deduction of that reserve. Another method which has been suggested would add any excess cash funds or outside investments actually on hand to the rate base, and charge the cost of service with any income actually received therefrom. This is hardly a solution at all; it does not stop depreciation accruals or deduction of the reserve, and in addition deprives the company of any benefit from outside investments once the opportunity for investment in the company itself has disappeared. ${ }^{33}$

\section{RATE OF RETURN}

The rate of return is generally defined as being a payment for three things: (I) pure interest, (2) risk, and (3) costs associated with marketing securities and raising capital. $^{34}$ Its importance can hardly be overestimated; for example, if an original 6 per cent rate of return is assumed, an adjustment of one-half of one per cent is equivalent to a change in the rate base of more than 8 per cent.

It is very difficult to state what the current policy of the Commission is with regard to the rate of return. Prior to I952, the Commission had used a 6 per cent rate of return as a more or less standard policy without any appreciable discussion. In 1952, in its now celebrated decision in Northern Natural Gas Company, ${ }^{35}$ the Commission adopted a rate of return of $5 \frac{1}{2}$ per cent on a determination based exclusively on the historical cost of money. ${ }^{36}$ The Commission continued this his-

\footnotetext{
${ }^{32}$ Apparently something approximating this is what Clemens had in mind in the quotation eited in note 28 , supra.

${ }^{33}$ This method was suggested in Report of the Commattee on Depreciation, Nat. Ass'n Railroad and Utulties Commissioners 44 (r944), cited by Clemens, op. cit. supra note r9, at 2Ir. The full N.A.R.U.C. report was not available at the time this article was written, and it is possible that the suggestion has been misinterpreted here.

34 Clemens, op. cit. supra note 19, at 218; Barnes, op. cit. supra note 19, at 517-518.

${ }^{36}$ Federal Power Commission Opinion No. 228, Docket Nos. G-1382, G-1533, and G-I607, 95 P.U.R. (N.s.) 289 (I952).

${ }^{36}$ This determination was reversed by the Court of Appeals for the Eighth Circuit, in Northern Natural Gas Co. v. Federal Power Comm'n, 206 F. 2d 690 (8th Cir. 1953), not on the ground that the determination was incorrect, but on the ground that the Commission did not fully explain its reasons for the determination or the facts underlying such reasons.
} 
torical cost of money policy for a time; then, during 1953 , In the Matter of the United Fuel Gas Company, 37 it allowed a rate of $61 / 4$ per cent by considering factors in addition to the historical cost of money. One guess is as good as another as to where we go from here. ${ }^{37^{a}}$

This article for obvious reasons cannot attempt a detailed analysis of the problems associated with the determination of the rate of return; transcripts of recent rate cases heard by the Commission literally contain volumes on this one subject. Furthermore, it is one of the most elusive and ethereal elements ever to confront an industry, a commission or the courts. This is demonstrated by the fact that it has repeatedly been stated by writers-including this one-commissions, and courts, that it can be determined only by the exercise of informed judgment in the light of all relevant facts and circumstances. While this is probably as good a description as can be given, it must be confessed that it certainly would help to know what it means in concrete terms.

However, there are some comments that deserve to be made about the practice of the Commission in connection with its rate of return allowance for natural gas companies. Admittedly the cost of money, both historical and current, should be considered, but so should the myriad other factors and circumstances presented by competent experts in volume after volume of testimony and exhibits to the Commission. If any consideration has been given to such other factors, the Commission's more recent opinions are barren of any evidence of it, at least prior to the United Fuel case. ${ }^{38}$ The least to which the natural gas industry is entitled after spending thousands of dollars, and days, weeks, and even months in the preparation of testimony relating to the rate of return, is that the Commission indicate where and to what extent it agrees or disagrees with that presentation. Failure to do so leaves natural gas companies and their counsel hopelessly confused in planning future presentations to the Commission. The fact appears to be that the Commission either has been unwilling to clarify its position, or unable to do so because it has arrived at no final determination.

A second observation is that the staff of the Commission frequently takes no

${ }^{37}$ F. P. C. Docket Nos. G-1781 and 2055, Opinion No. 258, issued Aug. 7, 1953; aff'd on rehearing, Opinion No. $258 \mathrm{~A}$, issued Nov. 19, 1953.

37a Since the first draft of this article, the Commission has determined, in Panhandle Eastern Pipe Line Company, stipra note 14 , that a return of $53 / 4$ per cent was reasonable under the circumstances presented in that case.

${ }^{38}$ In Northern Natural Gas Co. v. Federal Power Comm'n, supra note 36 , the court stated (pp. 722-723):

"The Commission has not successfully explained why it considers ... [a $5^{1 / 2}$ per cent] rate reasonable other than that it provides a yield to the common stock owners of Northern comparable or greater amounts than those yielded by other natural gas companies. Against that consideration we find the following in the record (of which there is no mention in the Commission's Opinion):

"(I) Voluminous testimony, both oral and written, on behalf of the petitioner. . .

"(2) The findings of the Presiding Examiner. . . .

"(3) The testimony of the expert witness called by the Commission. . . .

"(4) The fact that no witness, as far as our examination of the record discloses, testified to a rate as low as $5^{1 / 2}$ per cent" (emphasis supplied). 
position with respect to the reasonable rate of return on the record of the case. ${ }^{30}$ The staff does present a mass of undigested data and statistics, usually related solely to the historical cost of money, "for the information of the Commission," and may state that a return not in excess of a given figure would be reasonable. Seldom if ever does the staff recommend a stated rate of return with specific reasons therefor; at the same time the staff customarily vigorously attacks the company's presentation. It seems only reasonable to ask any objector to state what it does approve, if such objector has already stated it disapproves the only position taken on the record of the case.

Finally, the Commission's, and particularly the staff's, emphasis on the historical cost of money to the point of making it synonymous with the rate of return, has resulted in little or no consideration being given to the element of risk involved or to adjustments necessary to meet changing general price levels. There is a definite risk involved; the natural gas industry is a competitive industry and the competition is becoming increasingly severe as the field price of gas and other costs increase. The natural gas industry has exceptionally high fixed costs, and the risks associated with those high fixed costs are being shifted more and more to the natural gas company and away from the distributing utilities by means of rate patterns which overemphasize commodity charges as against demand charges and eliminate or reduce minimum commodity charges. In addition, there is the over-all and indeterminate risk of industry obsolescence.

The Commission has given no consideration to fluctuations in the general price level at all. This is despite the fact that virtually all exponents of an original cost rate base approve recognition of such fluctuations by varying the rate of return, and the Commission itself at one time took the position that this would be done. ${ }^{40}$ Cynics have been heard to comment that the Commission will revive that position and give effect to those fluctuations as soon as a definite deflationary trend appears.

The dangers inherent in the use of historical cost of money as the rate of return hardly need to be pointed out. ${ }^{41}$ It removes all incentive for obtaining cheap money arid for efficient operation, and puts the industry on the highway to public owner-

${ }^{39}$ Whether the staff takes a definite position off the record in memoranda submitted to the Commission, or simply takes no position at all at any time, is a matter known only to the Commission and its staff. Preliminary reports of the Committees of the Independent Natural Gas Association, referred to in note I2, supra, indicate a strong desire on the part of the industry to require all staff memoranda to be made part of the public record. Failing this, an attempt should be made to amend Section 5 (c) of the Administrative Procedure Act, 5 U. S. C. $\$ \mathrm{roo}_{4}(\mathrm{c})$, and the Commission's Rules $1.30(\mathrm{f})$, so as to bar staff members participating in the hearing from advising the Commission of the record in rate cases as well as in other matters.

${ }^{10}$ In its amicus brief to the Supreme Court in Railroad Commission of California v. Pacific Gas and Electric Co., 302 U. S. 388 (I938), the Commission stated, at pages 39-40:

“. . In times of prosperity the rates of return, which rates are derived from the study of economic conditions and earnings of business in general, will be increased to give the utilities and investors therein rates comparable to those being made on investments in other business undertakings which are attended by corresponding risks and uncertainties."

${ }^{11}$ For a more detailed discussion of this point, see Francis, Federal Regulation of Interstate Shipntent and Sale of Gas, Fourth Anntal Institute on OIb and Gas Law and Taxation I03, irg el seq. (Southwestern Legal Foundation, 1953), and sources there cited. 
ship. In addition, it accomplishes nothing so long as other costs are not fixed or relatively fixed, for there is no escape from the fact that the natural gas industry is a competitive industry and that its price in the market area sooner or later will reach competitive levels no matter how low the return to an individual company is cut. Unreasonably low returns simply mean that an unearned increment of value is passed to the nonaffiliated producer or other suppliers of material or labor or to the consumer at the expense of the natural gas industry. ${ }^{42}$

\section{Conclusion}

The Commission must be complimented in many respects: it has been a leader in the regulatory field in correction of willful abuses by management; it is now correcting many defects in administration of rate cases; it has exercised a strict and continuous control of accounting practices and rates; it is fully informed on the operations of the industry it regulates and substantially all of its employees can fairly be said to be genuinely expert. True it is that most industry leaders have been at variance with the views of a few staff members occupying key positions but such is not a situation to be wholly unexpected. Changing Commission personnel, observing past errors, can fairly be expected to recognize any justifiable complaints, and correct any fundamental staff procedural methods or objectives.

As opposed to this, the Commission must be criticized for failure always to take an objective viewpoint and to base its decisions on economic facts as distinguished from political expediency; ${ }^{43}$ and while it is to be complimented on obtaining a staff of competent technical experts, it must also be criticized for at least allowing the impression that the staff has on occasion become so powerful as to impose its judgment on the Commission.

I can think of no more fitting conclusion to this article than to repeat the plea of the late R. H. Hargrove ${ }^{44}$ in his opening statement to the Commission as a witness in its natural gas investigation, Docket No. G-580:

Our analysis should begin with a restatement of the functions of a Natural Gas Company. These functions are to purchase gas where produced and gathered, transport the same through transmission facilities and thereupon sell and deliver it to the ultimate consumers, in the case of direct industrial sales, and to distribution companies for resale to ultimate consumers for both domestic and industrial usage.

The project requires supplies of gas (commonly referred to as reserves), labor (principally skilled), capital and markets. Each component is just as essential as the others and a satisfactory operation requires that due regard be given to the interest of each group so that the fruits of the enterprise may be equitably distributed.

...

${ }^{2}$ If prices remain fixed or relatively fixed, the same results would ensue as described in connection with the loss of return through reduction of the rate base.

${ }^{4}$ Many observers are under the impression that the Commission's anxiety over the rising field price of gas and other costs has led it, under pressure from powerful consumer interests, to seek to maintain the lowest possible rate levels, as distinguished from the lowest reasonable rate levels, by attacking the most vulnerable variable subject to its complete control-the return to the company. It is hoped and believed that the reorganized Commission will render an equitable decision with respect to this policy.

"Then Vice President, United Gas Corporation; subsequently President, Texas Eastern Transmission Corporation. 
While the Natural Gas Act was enacted for the primary purpose of imposing regulation on rates and charges for gas sold in interstate commerce to local distributing companies for resale to ultimate consumers, the provisions of the Act are so broad and the impact of this regulation is so important that as a practical result the economy of Natural Gas Companies in all their operations can either be nurtured or destroyed by the manner in which the Act is administered. This responsibility becomes even more grave in the light of the tendency of the Supreme Court, as evidenced in its recent decisions, to refuse to review the orders of the Commission except to determine if the end result is disaster or confiscation. The end result of any one order could seldom be disaster. The cumulative result of a series of orders could well be disaster. This existing legal situation makes it highly important that the Commission should be certain, in the issuance of its important orders, that such are not merely legally supportable, but that they are just, fair and reasonable. The responsibility of the administrative function is tremendously increased by reason of this present viewpoint of the Courts in testing the validity of administrative action.

In the light of these circumstances it must be emphasized that the Commission's concept of its duties must never be narrowed to look only to the establishment of the lowest possible rates to consumers, or any other single phase, but more broadly to the health of the enterprise as a whole, with due regard to the interest of each of the groups previously mentioned. 